\title{
The International Handbook on Gender, Migration and Transnationalism: Global and Development Perspectives
}

\author{
edited by Laura Oso and Natalia Ribas-Mateos \\ Cheltenham (UK) and Northampton, MA: Edward Elgar 2013 \\ ISBN 978-1-78195-146-0 \\ Softcover $\$ 70,512 \mathrm{pp}$.
}

\author{
Reviewed by Meng Yu \\ Department of Sociology, Memorial University of Newfoundland
}

As the editors remark, the scope of this book is ambitious. The book attempts to provide a comprehensive discussion of gender, migration, development, and transnationalism by bridging studies of the topic. In addition to a thorough introduction, the publication consists of six parts with twenty articles, the majority of which are reprints of the authors' previously published papers. To link globalization, gender, and migration together, the book adopts Saskia Sassen's conceptual framework. According to Sassen, starting as early as the 1980s, economic globalization processes (structural adjustment programs, opening up to foreign capital, and removal of state subsidies in the Global South) led to a sharp rise in female migration. At the end of the twentieth century, transnationalism reached a particularly high degree of intensity on a global scale, as a result of globalization and technological changes.

Prior to the 1990s, gender was relatively overlooked in studies of the links between migration and development. Although the compilation's first three parts all have the word "development" in them, the concept of development is not clearly defined. As pointed out in the book, the European conceptions of the link between migration and development were based on a modernizing vision of this relationship, which defines development exclusively within economic paradigms. Although both the collection's editors and some authors lament the lack of adoption of the concept of "human development" in relevant research, "human development" is not clearly defined in the book, either. Chapter four may shed some light on this concept, when it attempts to explain what "smart economics" is. "Smart economics" rationalizes "investing" in women and girls for more effective development outcomes, rather than "promoting women's rights for their own sake" (Chant 2013: 97).

The first chapter in Part One, by Beneria and associates, elaborates on the "feminization" of international migration framework. Around the year 2000, the average emigration rate of tertiary-education women from non-OECD countries was 17.6 per cent, exceeding that of men. The authors point out that although much of the early literature on international migration was focused on the "brain drain," little attention was given to the gender dimensions of the phenomenon. However, readers who expect to read about the gender aspect of the "brain drain" would be disappointed. This collection includes only one case study on skilled immigrant women, those who migrate from Poland to the UK.

Although Part Two of the book is devoted to "new theoretical and methodological issues in the study of female migration and development," the two articles in it do not seem to have covered methodological issues. Nonetheless, a strength of this book is the diverse methodologies used in its case studies: quantitative, qualitative, and mixed methods. Qualitative methods used in the book include in-depth interviews and ethnography. Among the quantitative methods, some articles use rather simple descriptive statistical analyses, and some adopt such complex models as Bayesian networks. However, a common problem with these quantitative articles is 
their lack of explanation as to why the methods are used. Another noteworthy point is that the majority of the case studies are from either Spain or Latin America, probably due to the fact both editors are based in Spain.

Part Three is composed of three case studies which examine immigrants and their children's transnational engagement. The authors point out that maintaining a transnational household and engaging in pendulum migration behaviour are strategies immigrants use to cope with structured discrimination and barriers to integration in the host society. An intriguing case study is on West African immigrants in the US, who send their children back to Africa to be raised in order to solve problems of discipline and avoid what they see as harmful interference by legal authorities. Still, none of the three articles seems to have a clear gender focus. One possible reason could be that the articles were either originally published somewhere else or written for a different project, and when they were revised, a critical gender perspective was not really adopted.

The authors in Part Four have different opinions on what transnationalism means to immigrants and their children. Catarino and Morokvasic believe that transnational spaces can be both obstacles and sources of opportunity. However, according to Hondagneu-Sotelo, transnationalism or post-nationalism does not provide a viable framework for immigrant rights. With two theoretical pieces and three case studies, using both quantitative and qualitative methods, Part Four is devoted to transnationalism. This section raises and tests some important theories on the gendered dynamics of integration and transnational engagement especially among second-generation immigrants. According to the article by Bachmeier et al., when compared with visiting parents' country of origin and remitting, the intention to return to live in parents' origin country constitutes the greatest attachment to the origin country. The results of their research show that second-generation women in Europe are less likely to entertain the possibility of return migration and second-generation men who are highly integrated into the host-country economy are the most likely to entertain the possibility of return.

Part Five of the book is titled "Global Production." However, its three articles are each on female immigration to Spain, remittances sent to Ecuador, and remittances from Spain to Ecuador. None of the articles seems to have a strong theoretical base on the relationship between gender and migration.

The book concludes with a section on the "global care chains." According to Setien and Acosta, "the concept of global care chains has come to problematize the issue of replacement as one of the strategies used by women to solve the care crisis," and "it has also been identified as a structural cause of gender inequality." Their article examines caregivers' access to social rights and social citizenship, an important issue in the feminization of international migration. However, another article on the temporary migrations of Riffian women between Morocco and Europe, based on ethnography, does not seem to give a very clear account of the subject matter.

Two themes that could have been developed more in-depth in this book are (1) human development and how that is related to gender justice in migration, and (2) whether transnationalism represents opportunities or obstacles for migrants of different genders. A lack of discussion on methodologies used in migration studies, and how they can apply to the study of feminization of international migration, is a weakness in this book. Last but not least, this international handbook on gender, migration, and transnationalism could become a stronger tool for students of migration if it were to include case studies from more diverse geographic locations. 